\title{
Association between the CYP1A1 gene polymorphism and susceptibility to emphysema and lung cancer
}

\author{
A M Cantlay, D Lamb, M Gillooly, J Norrman, D Morrison, C A D Smith, \\ D J Harrison
}

\begin{abstract}
Aim-To investigate cytochrome P4501A1 (CYP1A1) polymorphism and susceptibility to emphysema and lung cancer. Methods-A novel polymerase chain reaction (PCR) for genotyping the CYP1A1 polymorphism, corresponding to putative low or high enzyme activity, was developed to genotype lung cancer resection samples which had been assessed macroscopically for the presence of centriacinar and panacinar emphysema. Samples were collected and genotyped from a group of patients with chronic obstructive airways disease. A control group of anonymous blood donations was genotyped to determine the basal levels of the polymorphism in the Scottish population. Results-The high activity allele of the CYP1A1 gene is associated with susceptibility to centriacinar emphysema and lung cancer but not panacinar emphysema. CYP1A1 polymorphism is not linked to lung cancer in the absence of emphysema, nor to chronic obstructive airways disease which is the clinical manifestation of emphysema, particularly of the panacinar type.

Conclusions-Susceptibility to emphysema and lung cancer is associated with polymorphism of the P4501A1 gene. A trend towards damage of centriacinar pattern has been detected, which supports the theory that centriacinar emphysema results from local, direct damage to the respiratory bronchioles from exposure to cigarette smoke.
\end{abstract}

(f Clin Pathol: Mol Pathol 1995;48:M210-M214)

Keywords: CYP1A1 polymorphism, emphysema, lung cancer, cigarette smoke.

Department of Pathology, Medical School, University of Edinburgh, Teviot Place, Edinburgh EH8 9AG

A M Cantlay

D Lamb

M Gillooly

J Norrman

C A D Smith

D J Harrison

Department of Respiratory Medicine D Morrison

Correspondence to: Dr D J Harrison.

Accepted for publication 26 April 1995 proteases, particularly elastase, during their inflammatory response. ${ }^{8}$ In rats emphysema has been induced by administration of elastase to the lungs. ${ }^{9}$ Antiproteases protect the structure
A single inhalation of cigarette smoke contains of cell membranes and structural components ${ }^{2}$ smoke can stimulate macroph to release chemotactic factors which rec inflammatory cells ${ }^{56}$ and nicotine has been of the lung from destruction by proteases such as elastase and collagenase. ${ }^{8}$ Oxidants present in cigarette smoke inhibit the action of antiproteases, further reducing the protective capacity of the lungs. ${ }^{10}$ Cigarette smoke causes at least two diseases of major clinical importance, lung cancer and emphysema.

The lungs are protected from the toxic effects of cigarette smoke by antiproteases, antioxidants and xenobiotic metabolising enzymes. ${ }^{1}$ In the lung both cancer and emphysema induced by cigarette smoke may result from variation in the protective capacity of lung tissue. Xenobiotic metabolising enzymes metabolise exogenous compounds, which may be toxic, to forms which are more easily excreted in the urine or bile. ${ }^{11}$ This metabolism may be an important primary defense against lung injury resulting from exposure to cigarette smoke. Variation in interindividual expression of metabolising enzymes may result in the differential ability of tissues to protect against disease.

Several of the major xenobiotic metabolising enzymes are polymorphic at the genetic level. These include cytochrome P4502D6, ${ }^{12}$ glutathione $\mathrm{S}$-transferase $\mathrm{M} 1^{13}$ and $\mathrm{N}$-acetyl transferase. ${ }^{14}$ Association between some of these enzyme polymorphisms and cancer susceptibility has been demonstrated ${ }^{15}$ - for example, both cytochrome P4502D6 and glutathione S-transferase M1 polymorphisms have been associated with susceptibility to lung cancer, and the $\mathrm{N}$-acetyl transferase 2 gene polymorphism has been implicated in bladder and colon cancers.

Cytochrome P4501A1 is a phase I metabolising enzyme which may activate procarcinogens and xenobiotics to their full carcinogenic and electrophilic forms. ${ }^{16} \mathrm{Ex}-$ pression of this enzyme is primarily extrahepatic $^{17}$ and is widespread in the lung. ${ }^{18}$ CYP1A1 expression is inducible by polycyclic aromatic hydrocarbons such as benzo[a]pyrene and 3-methylcholanthrene, ${ }^{1920}$ which form a major component of cigarette smoke. ${ }^{21} \mathrm{~A}$ point mutation in exon 7 of the CYP1A1 gene results in an amino acid substitution from an isoleucine to a valine. ${ }^{22}$ This mutation occurs in the region of the gene which encodes the heme binding motif of the protein, and studies of benzo[a]pyrene metabolism have shown that the valine protein demonstrates almost twice the enzyme activity of the isoleucine protein. ${ }^{16}$ This polymorphism is linked to a $M s p I$ restriction enzyme fragment length polymorphism in the $3^{\prime}$ region of the gene, ${ }^{22}$ which is associated 


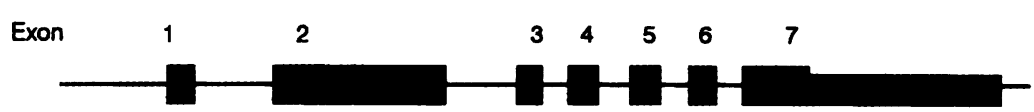

5' TGT ATC GGT GAG ACCATI CCC CGC TGG GAG GTC TIT 3' isoleucine allele Cys lle Gly Glu Thr lle Ala Arg Trp Glu Val Phe

5' TGT ATC GGT GAG ACC GTT GCC CGC TGG GAG GTC TIT 3' Cys lle Gly Glu Thr Val Ala Arg Trp Glu Val Phe

Downstream primer 3' AC CGG GCG ACC CTC CAG AAA 5'

Figure 1 Schematic diagram of the CYP1A1 gene. Sequences of the two alleles of the CYP1A1 gene are shown, along with the downstream primer, which introduces a base change to the amplimer. Following PCR, the base mismatch introduced into the amplimer creates a NcoI site (box) in the Isoleucine allele only, the site is absent in the Valine allele. lation of 281 individuals. Fifty one blood samples from patients with clinical lung disease were also collected.

DNA EXTRACTION AND PCR ANALYSIS

DNA extraction from paraffin wax embedded lung samples with no evidence of carcinoma and blood samples was carried out as described previously. ${ }^{32}$ Genotyping was carried out by PCR analysis using buffer and $1.5 \mathrm{mM} \mathrm{MgCl}_{2}$ (Promega, Southampton, UK), $150 \mathrm{mM}$ deoxynucleotides (Pharmacia, Milton Keynes, UK), 5\% DMSO (Sigma, St Louis, Missouri, USA), 25 pmoles primer (Oswell DNA Services, Edinburgh, UK), and 2.5 units of Taq polymerase (Promega, UK). The primers used were: upstream, 5'-AAAGGCTGGGTCCACCCTCT-3'; and downstream, 5'AAAGACCTCCCAGCGGGCCA-3' (fig 1).

The downstream primer incorporated a mismatched base to engineer a NcoI restriction enzyme site in the PCR products derived from the Ile ${ }^{462}$ allele of the gene. This restriction site is lost in the $\mathrm{Val}^{462}$ allele of the gene. The primers amplify both alleles and the genotypes are distinguished by $\mathrm{NcoI}$ digestion of the products. A NcoI restriction enzyme site located upstream of the mutation in either genotype serves as a positive control for PCR product digestion. PCR products were electrophoresed in 3\% NuSeive and SeaKem agarose (FMC Bioproducts, Rockland, Maine, USA), and restriction enzyme digestion fragments were electrophoresed in 3\% Metaphor agarose (FMC Bioproducts). We also obtained blood samples from patients with chronic obstructive airways disease. Chronic obstructive airways disease is believed to be the clinical manifestation of emphysema $^{2728}$; however, this clinical manifestation is more commonly seen in panacinar rather than centriacinar emphysema. ${ }^{29}$ Previous strategies for analysis of the exon 7 CYP1A1 polymorphism have made use of specific differential polymerase chain reaction (PCR) priming of the allelic variants of the gene, and have relied on high specificity of priming. ${ }^{30}$ We developed a novel PCR assay to genotype paraffin wax embedded lung tissues for the exon 7 polymorphism of the CYP1A1 gene, as use of high specificity primers relies on very stringent conditions which may reduce the yield of PCR amplimers.

\section{Methods}

Lung resection specimens $(n=129)$ from smokers with lung cancer were collected. The presence, type and extent of emphysema was assessed macroscopically in non-involved lobes and this assessment was confirmed by morphometric microscopic analysis of alveolar wall surface area per unit volume (AWUV). ${ }^{31}$ All emphysema cases were of mild or moderate disease severity, with a forced expiratory volume in one second $\left(\mathrm{FEV}_{1}\right)$ of at least 1.4 , as patients must be sufficiently fit to recover from surgery.

Blood samples collected from a blood donor clinic served as an anonymous control popu-

\section{STATISTICAL ANALYSES}

Odds ratios and confidence intervals were used to analyse the frequencies of the CYP1A1 genotypes, significance testing was by $\chi^{2}$ analysis. ${ }^{33}$

\section{Results}

DISEASE INFORMATION

No significant differences in age, sex, or tumour type were found within the study populations. The median $\mathrm{FEV}_{1}$ of chronic obstructive airways disease cases was $1 \cdot 1$, and $2 \cdot 2$ for the biopsy study group. Smoking histories were recorded where possible in pack years of exchronic obstructive airways disease group was 35 , while the biopsy cases had a median of 46 pack years.

Of the 129 lung cancer samples studied, 42 had no macroscopic emphysema, 34 showed centriacinar patterns of damage, 17 samples had panacinar emphysema, and 36 lung biopsy specimens had both centriacinar and panacinar forms of emphysema.

\section{GENOTYPING OF CYP1A1 GENE} POLYMORPHISM

Each amplimer analysed had a diagnostic NcoI restriction enzyme site and a second constant control NcoI site, which enabled distinction of the CYP1A1 genotype of the individual. PCR posure, and the median pack years for the analysis and subsequent enzyme restriction 
Table 1 CYP1A1 genotypes for the disease groups and control group for statistical comparison

\begin{tabular}{|c|c|c|c|c|c|c|c|c|}
\hline Subjects & $\begin{array}{l}\text { Ile/Ile } \\
\text { genotype }\end{array}$ & $\begin{array}{l}\text { Ile/Val } \\
\text { genotype }\end{array}$ & $\begin{array}{l}\text { Val/Val } \\
\text { genotype }\end{array}$ & $\begin{array}{l}\text { Total } \\
\text { cases }\end{array}$ & $\begin{array}{l}\chi^{2} v \\
\text { controls }\end{array}$ & $p$ value & $\begin{array}{l}\text { Odds } \\
\text { ratio }\end{array}$ & $\begin{array}{l}95 \% \text { confidence } \\
\text { limits }\end{array}$ \\
\hline Controls & $\begin{array}{l}245 \\
(87 \%)\end{array}$ & $\begin{array}{l}33 \\
(12 \%)\end{array}$ & $\begin{array}{l}3 \\
(1 \%)\end{array}$ & 281 & - & - & - & - \\
\hline All lung cancers & $\begin{array}{l}106 \\
(82 \%)\end{array}$ & $\begin{array}{l}21 \\
(16 \%)\end{array}$ & $\begin{array}{l}2 \\
(2 \%)\end{array}$ & 129 & $1 \cdot 81$ & $\begin{array}{l}\text { Not } \\
\text { significant }\end{array}$ & $1 \cdot 48$ & $0 \cdot 83-2 \cdot 61$ \\
\hline Cancer with no emphysema & $\begin{array}{c}39 \\
(93 \%)\end{array}$ & $\begin{array}{l}3 \\
(7 \%)\end{array}$ & 0 & 42 & $1 \cdot 11$ & $\begin{array}{l}\text { Not } \\
\text { significant }\end{array}$ & 0.52 & $0 \cdot 16-1 \cdot 77$ \\
\hline Cancer with emphysema & $\begin{array}{c}67 \\
(77 \%)\end{array}$ & $\begin{array}{l}18 \\
(21 \%)\end{array}$ & $\begin{array}{l}2 \\
(2 \%)\end{array}$ & 87 & $5 \cdot 33$ & $0 \cdot 021$ & $2 \cdot 03$ & $1 \cdot 10-3 \cdot 73$ \\
\hline Chronic obstructive airways disease & $\begin{array}{c}42 \\
(82 \%)\end{array}$ & $\begin{array}{c}9 \\
(18 \%)\end{array}$ & 0 & 51 & $1 \cdot 29$ & $\begin{array}{l}\text { Not } \\
\text { significant }\end{array}$ & $1 \cdot 46$ & $0 \cdot 66-3 \cdot 25$ \\
\hline
\end{tabular}

Table 2 CYP1A1 genotypes of cases with emphysema and lung cancer divided by pattern of emphysema

\begin{tabular}{|c|c|c|c|c|c|c|c|c|}
\hline Types of emphysema & $\begin{array}{l}\text { Ile/Ile } \\
\text { genotype }\end{array}$ & $\begin{array}{l}\text { Ile/Val } \\
\text { genotype }\end{array}$ & $\begin{array}{l}\text { Val/Val } \\
\text { genotype }\end{array}$ & $\begin{array}{l}\text { Total } \\
\text { cases }\end{array}$ & $\begin{array}{l}\gamma^{2} v \\
\text { controls }\end{array}$ & $p$ value & $\begin{array}{l}\text { Odds } \\
\text { ratio }\end{array}$ & $\begin{array}{l}95 \% \text { confidence } \\
\text { limits }\end{array}$ \\
\hline Centriacinar alone & $\begin{array}{l}25 \\
(73 \cdot 5 \%)\end{array}$ & $\begin{array}{l}9 \\
(23 \cdot 5 \%)\end{array}$ & 0 & 34 & $4 \cdot 62$ & 0.035 & $2 \cdot 45$ & $1 \cdot 06-5 \cdot 67$ \\
\hline Panacinar alone & $\begin{array}{l}15 \\
(88 \%)\end{array}$ & $\begin{array}{l}i \\
(6 \%)\end{array}$ & $\begin{array}{l}1 \\
(6 \%)\end{array}$ & 17 & 0.02 & $\begin{array}{l}\text { Not } \\
\text { significant }\end{array}$ & 0.91 & $0 \cdot 20-4 \cdot 10$ \\
\hline Both & $\begin{array}{l}27 \\
(75 \%)\end{array}$ & $\begin{array}{l}8 \\
(22 \%)\end{array}$ & 1 & 36 & 3.89 & 0.049 & $2 \cdot 25$ & $0 \cdot 98-5 \cdot 17$ \\
\hline
\end{tabular}

analysis yielded specific fragments which were easily visualised on agarose gels (fig 2).

The control group numbered 281 samples, of which $87 \%(244 / 281)$ were homozygous for the Ile ${ }^{462}$ allele, $12 \%$ (34/281) were heterozygous and $1 \%$ (three of 281 ) were homozygous for the valine allele of the CYP1A1 gene (table 1). In comparison, of the 129 lung resection cases, $82 \%$ (105/129) exhibited homozygosity

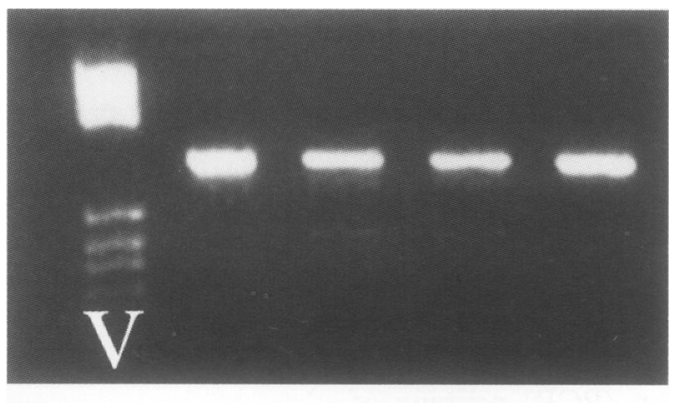

(A)

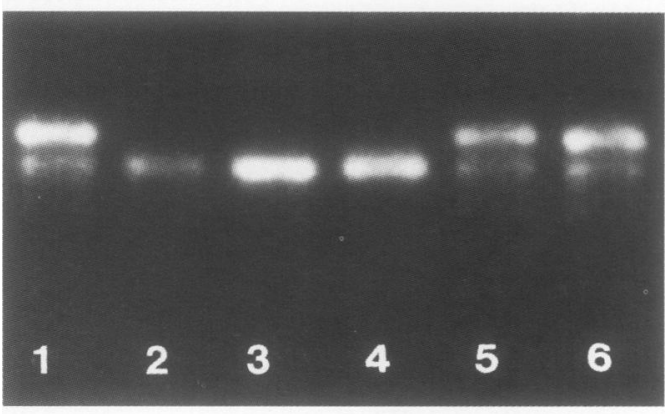

(B)

Figure 2 (A) Results of a PCR of the CYP1A1 gene. DNA molecular marker $V$ is shown in the lefthand lane, with PCR amplimers in the remaining lanes. The amplimer (322 base pairs) lies between fragments of 434 and 267 base pairs of the marker. (B) Results of a Ncol digestion of the CYP1A1 amplimer. The two bands represent the two alleles of the gene, the higher molecular weight fragment (250 base pairs) representing the uncut valine allele of the gene, and the lower molecular weight band (231 base pairs) representing the cut isoleucine allele of CYP1A1. Lanes 1, 5 and 6 therefore represent heterozygotes for the two alleles, while lanes 2, 3 and 4 contain digestions from individuals homozygous for the common Isoleucine allele. at the Ile ${ }^{462}$ allele, $16 \%(21 / 129)$ were heterozygous for Ile ${ }^{462}$ while $2 \%$ (three of 129 ) exhibited $\mathrm{Val}^{462}$ homozygosity. This group was not significantly different from the control population.

In the group of patients with chronic obstructive airways disease, of the 51 samples, $82 \%(42 / 51)$ were homozygous for $\mathrm{Ile}^{462}$ and $18 \%$ (nine of 51 ) were heterozygous for the polymorphism. No individuals homozygous for the valine allele were found in this disease group, and no significant difference between this study group and the controls was seen.

To investigate the CYP1A1 gene polymorphism and susceptibility to emphysema, the total lung cancer study group was divided according to the pattern of emphysematous damage in the lung (table 2). When this was done, 42 samples showed no evidence of emphysema and of these, $93 \%(39 / 42)$ were Ile $^{462}$ homozygotes; $7 \%$ (three of 42 ) were heterozygotes. Centriacinar emphysema only was found in 34 cases and of these, $73.5 \%$ (25/ 34) were homozygous for the valine allele and $26.5 \%$ (nine of 34 ) were Ile/Val. Panacinar emphysema alone was present in 17 samples and $88 \%(15 / 17)$ were Ile ${ }^{462}$ homozygotes, $6 \%$ (one of 17) were Ile/ Val, and $6 \%$ (one of 17) were homozygous for the $\mathrm{Val}^{462}$ allele. Both panacinar and centriacinar emphysemas were found in 36 of the lung cancer samples and homozygotes for the isoleucine allele accounted for $75 \%(27 / 36)$ of these cases, $22 \%$ (eight of 36 ) were heterozygotes and 3\% (one of 36) were $\mathrm{Val}^{462}$ homozygotes.

Of these disease groups, only those patients with centriacinar emphysema alone and both centriacinar and panacinar emphysema differed significantly from the controls. Odds ratios were 2.45 (95\% confidence limits $1 \cdot 06-5 \cdot 67)$ and $2 \cdot 25$ (95\% confidence limits $0 \cdot 98-5 \cdot 17$ ), respectively.

\section{Discussion}

We have found a statistically significant association of the rare, putative high activity allele 
of CYP1A1 in cases with both lung cancer and emphysema (odds ratios of $2 \cdot 45$ and $2 \cdot 25$ ) but not in cases with chronic obstructive airways disease or cancer alone. Clinical cases of chronic obstructive airways disease do not represent just emphysema but also include chronic abstructive airways disease secondary to chronic bronchitis. This may explain why a lack of CYP1A1 association is seen for this condition, but association with the polymorphism is seen with pathological emphysema. Previous studies investigating CYP1A1 and lung cancer have provided conflicting data. Whereas in Japanese populations CYP1A1 conferred a threefold increased risk of lung cancer, similar studies of Scandinavian populations have failed to find any association. ${ }^{2526}$ No study to date has considered the possibility that CYP1A1 may confer susceptibility not just to lung cancer but also to other forms of lung disease, such as emphysema. What do the results we have obtained suggest?

Firstly, although our data indicate that CYP1A1 is associated with lung cancer and emphysema, the increased relative risk we have found is rather small and is only significant when both diseases are present. However, emphysema and lung cancer are extremely prevalent diseases, hence even a slight increase in disease susceptibility conferred by this polymorphism may account for a large proportion of cases.

Secondly, the increased susceptibility to lung disease conferred by the CYP1A1 polymorphism appears to be an early event, occurring at a stage before the injury response pathway leading to cell death and inflammation has diverged from that leading to mutagenesis and eventual tumour progression. This is in keeping with the likely position of CYP1A1 in the pathway of cigarette smoke metabolismthat is, it is proximate to the insult by nature of its expression in lung parenchyma and role in phase I metabolism.

Thirdly, the effect of CYP1A1 genotype and phenotype on disease susceptibility will be influenced by other mechanisms of disease development. These may be more important than CYP1A1 in determining the likelihood of cigarette smoke injury to result in predominantly genotoxic or cytotoxic injury. Thus, certain protective mechanisms such as the glutathione dependant system, epoxide hydrolase, differences in proteolytic enzymes, or antiproteases may reduce the likelihood of cell damage caused by lipid or protein peroxidation leading to emphysema. It is perhaps significant that the cases with both lung cancer and emphysema had mild or moderate emphysema whereas the clinical group with chronic obstructive airways disease had severe diseasethat is, CYP1Al polymorphism contributes little towards susceptibility to severe, non-neoplastic lung injury.

Conversely, differences in DNA repair and other genes involved in recognising and eliminating DNA damage may be very important in determining whether or not tumorigenesis can occur. These mechanisms are likely to differ between individuals and consistent with this is the presence of known polymorphisms/mutations - for example, in the p53 gene and in the DNA mismatch repair system. ${ }^{34-36}$ These polymorphisms or mutations may contribute to interindividual differences in the capacity to eliminate DNA damage and therefore prevent mutations leading to tumorigenesis.

Only in cases with no bias towards, or away from, non-neoplastic or neoplastic lung disease would CYP1Al be expected to have a detectable effect on the susceptibility to disease rather than simply a more subtle underlying modification of mechanisms and responses to injury.

The results that we have obtained in this study show that a genetically determined difference in xenobiotic metabolism, in this case components of cigarette smoke, may alter the response of cells or tissue to injury and thus susceptibility to disease.

This work was supported by the Scottish Office Home and Health Department, and the Salvesen Trust.

1 Heffner JE, Repine JE. Pulmonary strategies of antioxidant defence. Am Rev Respir Dis 1989;140:531-54.

2 Farber JL. Mechanisms of cell injury by activated oxygen species. Environ Health Perspect 1994;102:17-24.

3 Harley RA, Tobacco. In: Dail DH, Hammer SP, eds. Pulmonary pathology. New York: Springer Verlag, 1988:63749.

4 Weitzman SA, Gordon LI. Inflammation and cancer: role of phagocyte-generated oxidants in carcinogenesis. Blood of phagocyte-gen

5 Hunninghake G, Gadek J, Crystal R. Human alveolar macrophage neutrophil chemotactic factor: stimuli and partial characterization. $\mathcal{F}$ Clin Invest 1980;66:473-83.

6 Merril WW, Naegel GP, Matthay RA, Reynolds HY. Alveolar macrophage-derived chemotactic factor. Kinetics of in vitro production and partial characterization. $\mathcal{F}$ Clin Invest 1980;65:268-76.

7 Totti N, McCusker KT, Cambell EJ, Griffen GL, Senior RM. Nicotine is chemotactic for neutrophils and enhances neutrophil responsiveness to chemotactic peptides. Science 1984;223:169-71.

8 Aaron J. Elastases and Emphysema. Current assessment of the protease-antiprotease hypothesis. Am Rev Respir Dis 1985;132:417-33.

9 Aaron J. Biochemical links between cigarette smoking and pulmonary emphysema. f Appl Physiol 1983;55:285-93.

10 Evans MD, Pryor WA. Cigarette smoking, emphysema, and damage to $x 1$-proteinase inhibitor. Am $\mathcal{F}$ Physiol 1994; 266:L593-611.

11 Gibson GG, Skett P. Introduction to drug metabolism. 2nd edn. Glasgow: Blackie Academic and Professional, 1994.

12 Meyer UA. Pharmacogenetics: the slow, the rapid, and the ultrarapid. Proc Natl Acad Sci USA 1994;91:1983-4.

13 Board PG. Genetic polymorphisms of glutathione S-transferases in man. In: Hayes JD, Pickett CG, Mantle TJ, eds. Glutathione S-transferases and drug resistance. London: Taylor and Francis, 1990:232-41.

14 Grant DM. Molecular genetics of the $\mathrm{N}$-acetyltransferases. Pharmacogenetics 1993;3:45-50.

15 Smith CAD, Smith G, Wolf CR. Genetic polymorphisms in xenobiotic metabolism. Eur $\mathcal{F}$ Cancer 1994;30A:1921-35.

16 Kawajiri K, Nakachi K, Imai K, Watanabe J, Hayashi S-I. The CYP1A1 gene and cancer susceptibility. Crit Rev Oncol/Hematol 1993;14:77-87.

17 Omiecinski CJ, Redlich CA, Costa P. Induction and developmental expression of cytochrome P4501A messanger RNA in rat and human tissues: detection by the polymera

8 Antilla S, Vainio H, Hietanen E, Camus A-M, Malaveille $\mathrm{C}$, Brun $\mathrm{G}$, et al. Immunohistochemical detection of pulmonary cytochrome P4501A and metabolic activities associated with P4501A1 and P4501A2 isozymes in lung cancer patients. Environ Health Perspect 1992;98:179-82.

19 Kimura S, Gonzalez FJ, Nebert FJ. Tissue-specific expression of the mouse dioxin-inducible P1-450 and P3450 genes: differential transcriptional activation and mRNA stability in liver and extrahepatic tissues. Mol Cell Biol 1986;6:1471-7.

20 Kawajiri K, Gotoh O, Tagashira Y, Sogawa K, Fujii-Kuriyama Y. Titration of $\mathrm{mRNAs}$ for cytochrome P-450c and P-450d under drug-inductive conditions in rat livers by their specific probes of cloned DNAs. 7 Biol Chem 1984;259:10145-9.

21 Golding F. Smoking. In: Brewis RAL, Gibson GJ, Geddes DM, eds. Respiratory medicine. London: Baillière Tindall, 1990:445-60.

22 Hayashi S-I, Watanabe J, Nakachi K, Kawajiri K. Genetic linkage of lung cancer-associated MspI polymorphisms with amino acid replacement in the heme-binding region 
of the human cytochrome P-4501Al gene. $f$ Biochem 1991;110:407-11.

23 Kawajiri K, Nakachi K, Imai K, Yoshii A, Shinoda N, Watanabe J. Identification of genetically high risk individuals to lung cancer by DNA polymorphisms of the

24 Nakachi K, Imai K, Hayashi S-I, Watanabe J, Kawajiri K. Genetic susceptibility to squamous carcinoma of the lung

25 Tefre T, Ryberg D, Haugen A, Nebert DW, Skarg V, Brogger $A$, et al. Human CYP1A1 (cytochrome $P_{1} 450$ ) gene: lack of association between the MspI restriction fragment length polymorphism and incidence of lung cancer in a Norwegian population. Pharmacogenetics 1991;1:20-5.

26 Hirvonen A, Husgafvel-Pursiainen K, Karjalainen A, Antilla S, Vainio H. Point-mutational MspI and Ile-Val polymorphisms closely linked in the CYP1A1 gene: lack of association with susceptibility to lung cancer in a Finnish study population. Cancer Epidemiology, Biomarkers and study population. Cancer

27 Lamb D. Pathology. In: Calverley P, Pride N, eds. Chronic obstructive pulmonary disease. London: Chapman and Hall, 1995:9-3

28 Greaves IA, Colebatch HJH. Observations on the pathogenesis of chronic airflow obstruction in smokers: im- plications for the detection of "early" lung disease. Thorax 1986;41:81-7.

29 Kim WD, Eidelman DH, Izquierdo JL, Ghezzo H, Saetta MP et al. Centrilobular and panlobular emphysem MP, et al. Centrilobular and panlobular emphysema in Am Rev Respir Dis 1991;144:1385-90.

30 Hayashi S-I, Watanabe J, Kawajiri K. PCR detection of an A/G polymorphism within exon 7 of the CYP1A1 gene. A/G polymorphism within exon

31 Gillooly M, Lamb D. Airspace size in lungs of lifelong nonsmokers: effect of age and sex. Thorax 1993;48:39-43.

32 Cantlay AM, Smith CAD, Wallace WA, Yap P-L, Lamb D, Harrison DJ. Heterogeneous expression and polymorphic genotype of glutathione S-transferases in human lung. Thorax 1994;49:1010-14.

33 Armitage P. Statistical methods in medical research. Oxford: Blackwell Scientific Publications, 1971.

34 Service RF. Stalking the start of colon cancer. Science 1994; 263:1559-60.

35 Papadopoulos N, Nicolaides NC, Wei Y-F, Ruben SM, Carter KC, Rosen CA, et al. Mutation of a mutL homologue in hereditary colon cancer. Science 1994;263:16259 .

36 Marx J. New colon cancer gene discovered. Science 1993; 260:751-2. 